\title{
Genetic diversity analysis in Gladiolus genotypes (Gladiolus hybridus Hort)
}

\author{
Archana Bhajantri* and V. S. Patil \\ Department of Horticulture, Agriculture College Dharwad, University of Agricultural Sciences, Dharwad-580005 \\ (Karnataka), INDIA \\ *Corresponding author. E-mail: archana.bb@gmail.com
}

Received: December 15, 2015; Revised received: May 28, 2016; Accepted: July 31, 2016

\begin{abstract}
In the present investigation, thirty gladiolus (Gladiolus hybridus Hort) genotypes were assessed to know the nature and magnitude of genetic divergence using Mahalanobis $D^{2}$ statistics. Genetic diversity study indicated that among the 17 characters, most of the flower characters contributed towards diversity. Floret diameter contributed maximum towards genetic divergence followed by number of florets per spike, vase life, spike length and plant height.Thirty genotypes were grouped into 8 clusters and among them, cluster I was the largest with 9 genotypes followed by cluster II having 7 genotypes, and IV cluster 6 and cluster III with 3 genotypes each. Clusters were of V, VII and VIII solitary type means they having only one genotype in their group. Divergence values $\left(D^{2}\right.$ value) ranged from zero to 7.97 indicating considerable amount of moderate variability in the material studied. Information generated from the present study would be useful in selection of parents for future breeding programme for flower quality improvement in gladiolus. It is desirable to select genotypes from clusters having high cluster means and also with high flower character like spike length as parents for future recombination breeding programmes.
\end{abstract}

Keywords: Cluster mean, Genetic divergence, Gladiolus genotypes, Intra and inter cluster

\section{INTRODUCTION}

Gladiolus plant is a tender herbaceous perennial belongs to family Iridaceae, growing from both seeds and corms. It stands fourth in the international cut flower trade after carnation, rose and chrysanthemum. Though India has suitable agro-climatic conditions for gladiolus cultivation, it is being grown over an area of 1200 ha with a production of 1905.88 lakh spikes. Gladiolus known as queen of the bulbous plant is very popular as cut flower, both with the consumer and florist alike because of its many spike forms, color and color combinations, an advantage in every floral arrangement (Bushman,1990)

$\mathrm{D}^{2}$ statistic has been employed widely to resolve genetic divergence at intervarietal, subspecies and species levels in classifying problems in crop plants (Murthy and Tiwari, 1967 and Siddique and Swaminathan, 1971).Morphological traits have long been used to estimate systematic relationships in crops and ornamentals (Wen and Hsaio,2004). In the process of formulating the gladiolus crop improvement programmes, understanding about the nature and degree of genetic divergence available in the germplasm plays a pivotal role. Genetic divergence existing in the population helps in selecting suitable parents for hybridization programme. Germplasm characterization is an important link between the conservation and utilization of plant genetic resources. Molecular techniques allow researchers to identify accessions at the taxo- nomic level, assess the relative diversity within and among species and locate diverse accessions for breeding programmes

Therefore, present investigation was undertaken to examine the nature and magnitude of genetic divergence in thirty gladiolus genotypes.

\section{MATERIALS AND METHODS}

Present investigations were carried out with thirty varieties of gladiolus obtained from Indian Institute of Horticulture Research, Bangalore which was selected on the basis of phenotypic variability in different quantitative characters. The experiments were conducted in Department of Horticulture, University of Agricultural Sciences Dharwad, during the year 201112. The genotypes were planted in randomized block design with two replications consisting of single row length of $3 \mathrm{mts}$ and 10 plants for each entry. seventeen observations were recorded on agronomic and flower attributes. The list of genotypes is given in the Table 1. Mahalanobis (1936) $\mathrm{D}^{2}$ statistics was used for assessing the genetic divergence thirty genotypes for different agronomic and flower traits. The generalized distance between any two populations is given by the following formula.

$$
\mathrm{D}^{2}=\Sigma \Sigma \lambda_{\mathrm{ij}} \mathrm{s}_{\mathrm{i}} \mathrm{s}_{\mathrm{j}}
$$

Where,

$$
\mathrm{D}^{2}=\text { Square of generalized distance }
$$

$\gamma_{i j}=$ Reciprocal of the common dispersal matrix 


$$
\begin{aligned}
& \mathrm{s}^{\mathrm{ai}}=(\mu \mathrm{i} 1-\mu \mathrm{i} 2) \\
& \mathrm{s}^{\mathrm{aj}}=(\mu \mathrm{j} 1-\mu \mathrm{j} 2) \\
& \mu=\text { General mean }
\end{aligned}
$$

\section{RESULTS AND DISCUSSION}

The assessment of genetic diversity using quantitative traits has been of prime importance in many contexts particularly in differentiating well defined populations. The germplasm in a self pollinated crop can be considered as heterogeneous sets of groups, since each group being homozygous within it. Selecting the parents for breeding program in such crops is critical because the success of such programme depends on the segregants of hybrid derivatives between the parents, particularly when the aim is to improve the quantitative characters like yield and related traits Sheikh and Khanday (2008).

The analysis of variance revealed significantly at $5 \%$ level of significance, differences among 30 genotypes for all the traits indicating sufficient genetic diversity among the genotypes studied on the basis of $\mathrm{D}^{2}$ values. The 30 gladiolus genotypes were grouped into 8 clus-

\begin{tabular}{|c|c|c|c|c|}
\hline $\begin{array}{l}\text { Sl } \\
\text { No }\end{array}$ & Genotype & Parentage & Color description & Source \\
\hline 1. & $\begin{array}{l}\text { American } \\
\text { Beauty }\end{array}$ & Unknown & $\begin{array}{l}\text { Petals carmine red, lower three petals inside and outside cream at lip } \\
\text { portion }\end{array}$ & \\
\hline 2. & Sylvia & $\begin{array}{l}\text { Comm Koehl x } \\
\text { Moorish King }\end{array}$ & $\begin{array}{l}\text { Cherry petals or } 2 \text { corlet, here and there blood red specks, lower two } \\
\text { inside petals butler cup yellow 5-6 red lines around } 1 \text { yellow long } \\
\text { streak. }\end{array}$ & \\
\hline 3. & Melody & Unknown & Peach pink petals lower 3 petals inside scarlet lip. & \\
\hline 4. & $\begin{array}{l}\text { Summer } \\
\text { Sunshine }\end{array}$ & Unknown & Florets are yellow with reddish orange in color. & \\
\hline 5. & Vadanapoli & Unknown & Florets are light to dark pink in color with whitish throat. & \\
\hline 6. & Copper King & Unknown & Florets are with fan shaped yellow throat on red base, ruffled. & \\
\hline 7. & Red Ginger & Unknown & Florets pink in color with whitish central throat. & \\
\hline 8. & Candiman & Unknown & Florets are dark pink in color with light pinkish central blotch. & \\
\hline 9. & Priscilla & $\begin{array}{l}\text { Diamond } \mathrm{x} \\
\text { Leana }\end{array}$ & Florets are pinkish move petals and yellowish white throat. & \\
\hline 10. & Jester Yellow & Jester Sport & Florets are yellow in color with greenish central blotch. & \\
\hline 11. & $\begin{array}{l}\text { White } \\
\text { Friendship }\end{array}$ & $\begin{array}{l}\text { (Maid of Or- } \\
\text { leansx Piardy) } \\
\text { x (Gloaming x } \\
\text { Seedling) }\end{array}$ & Florets are creamish white in color. & \\
\hline 12. & $\begin{array}{l}\text { White } \\
\text { prosperity }\end{array}$ & Unknown & Florets are white in color. & \\
\hline 13. & Eight Wonder & Unknown & Florets are yellow in color & \\
\hline 14. & Pacific & Unknown & $\begin{array}{l}\text { Florets are pure white in color, petals fading to light pink with red } \\
\text { blotch on throat petals heavily ruffled. }\end{array}$ & \\
\hline 15. & Light Purple & Unknown & Florets are light purple in colour petals are shaded with creem. & \\
\hline 16. & Peter Pears & $\begin{array}{l}\text { Salmoe } \mathrm{x} \\
\text { Maolete }\end{array}$ & Flowers are peach in colour medium in size. & \\
\hline 17. & Snow Princess & Unknown & Flowers ans florets are white in color. & \\
\hline 18. & $\begin{array}{l}\text { Apple } \\
\text { Blossom }\end{array}$ & $\begin{array}{l}\text { Beautys Blush } \\
\text { x Rose Charm }\end{array}$ & $\begin{array}{l}\text { Petals are delicate light pink with darker dots, ruffled open faced } \\
\text { flower. }\end{array}$ & IIHR, Ban- \\
\hline 19. & $\begin{array}{l}\text { Rose } \\
\text { Delight. }\end{array}$ & $\begin{array}{l}\text { Picardy x Early } \\
\text { Rose }\end{array}$ & & \\
\hline 20. & Arati & $\begin{array}{l}\text { Shieley x Mel- } \\
\text { ody }\end{array}$ & Poppy-red with purple-red and canary-yellow blotch & \\
\hline 21. & Tropic Sea & Unknown & $\begin{array}{l}\text { Petal lip portion royal purple, inside the below petals with creamy } 3 / 4 \\
\text { portion. }\end{array}$ & \\
\hline 22. & $\begin{array}{l}\text { Ham Van } \\
\text { Magareen }\end{array}$ & Unknown & Pale sober yellow semi open faced. & \\
\hline 23. & Ethyl Cav cole & Unknown & petals crimson (32), here and there white blotches & \\
\hline 24. & Summer Pearl & Unknown & Petals bluish pink, inside ivory base is cream. & \\
\hline 25. & Thumbelina & Unknown & Snow white with red margin & \\
\hline 26. & Oscar & Unknown & Deep velvety red and huge flowers & \\
\hline 27. & Red charm & Unknown & Flowers are blood red in colour small flowers and compact. & \\
\hline 28. & Legend & Unknown & Flowers are red with white throat ruffled and compact. & \\
\hline 29. & Tiger flame & Unknown & & \\
\hline 30. & Appollo & Unknown & Flower shades of orange, light salmon and deep yellow heavily ruffled. & \\
\hline
\end{tabular}
ters (Table3), there were 9 genotypes in cluster I, 7

Table 1. Gladiolus genotypes used for phenotypic diversity analysis. 
Table 2. Per cent contribution of 17 quantitative characters towards diversity in gladiolus genotypes.

\begin{tabular}{clcc}
\hline Sl. No. & \multicolumn{1}{c}{ Character } & Per cent contribution (\%) & Ranking \\
\hline 1 & Corm Weight $(\mathrm{gm})$ & 0.69 & 3.45 \\
2 & Corm diameter $(\mathrm{cm})$ & 2.53 \\
3 & Cormels per plant & 2.30 & \\
4 & Days taken for sprouting & 5.29 & $\mathrm{~V}$ \\
5 & Plant height (cm) & 2.76 \\
6 & Leaves per plant & 4.14 & \\
7 & Leaf width (cm) & 3.22 & \\
8 & Days taken for spike iniation & 1.38 & IV \\
9 & Days taken for first floret to show colour & 1.84 & \\
10 & Days taken for full emergence of spike & 5.75 & II \\
11 & Spike length (cm) & 0.00 & VI \\
12 & Rachis length (cm) & 1.54 & I \\
13 & Spike girth (cm) & 11.26 & III \\
14 & Florets per spike & 4.37 & 20.46 \\
15 & Inter floret length (cm) & 10.57 & \\
16 & Floret diameter $(\mathrm{cm})$ & & \\
17 & Vase life & & \\
\hline
\end{tabular}

Table 3. Grouping gladiolus genotypes based on $\mathrm{D}^{2}$ analysis.

\begin{tabular}{|c|c|c|c|}
\hline Sl. No. & Clusters & Number of genotypes & Name of the genotypes \\
\hline 1 & I & 3 & Sylvia ,Melody ,Summer Sunshine \\
\hline 2 & II & 7 & $\begin{array}{l}\text { Tropic Sea, Han Vam Meegreen Ethyl Cavcole, Legend, Summer } \\
\text { Pearl, Appollo, Thumbelina }\end{array}$ \\
\hline 3 & III & 9 & $\begin{array}{l}\text { White Friendship, White Prosperity, } \\
\text { Jester Yellow, Priscilla, Candiman, Red Ginger, Eight Wonder, } \\
\text { Copper King,Pacifica }\end{array}$ \\
\hline 4 & IV & 6 & $\begin{array}{l}\text { Peter pears, Snow Princess, Apple Blossom, Rose Delight, Arati, } \\
\text { Red Charm }\end{array}$ \\
\hline 5 & V & 1 & Vadanapoli \\
\hline 6 & VI & 2 & IIHR water mealon pink, White chiffer \\
\hline 7 & VII & 1 & Light Purple \\
\hline 8 & VIII & 1 & American Beauty \\
\hline
\end{tabular}

Table 4. Average intra and inter cluster $\mathrm{D}^{2}$ values of 8 clusters in gladiolus genotypes.

\begin{tabular}{cccccccccc}
\hline Sl. No. & Cluster & I & II & III & IV & V & VI & VII & VIII \\
\hline 1 & I & 2.72 & 6.92 & 6.88 & 7.18 & 4.11 & 6.47 & 7.97 & 3.46 \\
2 & II & & 3.46 & 5.13 & 5.22 & 5.20 & 6.09 & 4.81 & 7.37 \\
3 & III & & & 3.51 & 6.19 & 4.79 & 6.46 & 4.93 & 7.44 \\
4 & IV & & & & 3.89 & 5.60 & 5.44 & 4.60 & 7.65 \\
5 & V & & & & & 0.00 & 5.36 & 6.28 & 4.73 \\
6 & VI & & & & & & 2.48 & 6.16 & 6.75 \\
7 & VII & & & & & & & 0.00 & 8.49 \\
8 & VIII & & & & & & & & \\
\hline
\end{tabular}

Diagonal values indicate intra cluster distance

genotypes in II cluster, cluster III and VI having 3 and 2 genotypes in their cluster group and Clusters V, VI and VIII having single genotypes in their cluster group they called as solitary type. The grouping pattern of the genotypes suggested by no parallelism between genetic divergent and geographical distribution of genotypes. Desh Raj and Mishra (2006) and Pal et al (2006) reported that genotype diversity was independent of geographical region. Therefore selection of parents for hybridizations should be based on genetic diversity rather than geographical distribution.

Contribution of each character towards genetic diver- gence was estimated from the number of times that character appeared in first rank (Table 2). It was observed that floret diameter contributed maximum $(20.46 \%)$ towards genetic divergence followed by number of florets per spike $(11.26 \%)$, vase life $(10.57 \%)$, and spike length $(5.75 \%)$ and plant height (5.29\%). These characters showed highest contribution in differentiating at intra cluster level. Desh Raj and Mishra (1996) reported highest contribution from floret diameter, number of florets per plant and spike length. Another author Pal et al (2006) reported that vase life, spike length and plant height contributed 
Table 5. The nearest and farthest clusters based on $\mathrm{D}^{2}$ values in gladiolus genotypes

\begin{tabular}{|c|c|c|}
\hline $\begin{array}{c}\text { Clus- } \\
\text { ters }\end{array}$ & $\begin{array}{c}\text { Nearest cluster with } \\
D^{2} \text { value }\end{array}$ & $\begin{array}{c}\text { Farthest cluster with } \mathrm{D}^{2} \\
\text { value }\end{array}$ \\
\hline $\bar{I}$ & $\mathrm{~V}(4.11)$ & $\begin{array}{l}\text { VI (7.97) } \\
\end{array}$ \\
\hline II & VII (4.81) & VIII(7.37) \\
\hline III & $\mathrm{V}(4.79)$ & VIII(7.44) \\
\hline IV & VII(4.60) & VIII(7.65) \\
\hline V & $\mathrm{I}(4.11)$ & VII(6.28) \\
\hline VI & $\operatorname{IV}(5.44)$ & VIII(6.75) \\
\hline VII & $\mathrm{VI}(6.16)$ & VIII(8.49) \\
\hline VIII & $\mathrm{I}(3.46)$ & VIII(8.49) \\
\hline
\end{tabular}

Values in parenthesis indicate intercluster $\mathrm{D}^{2}$ values

highest in gladiolus diversity studies. Thirty genotypes were grouped into 8 clusters (Table 3) and among them, cluster I was the largest with 9 genotypes followed by cluster II and IV each with 7 and 6 genotypes and cluster III with 3 genotypes Cluster VI 2 genotypes. Rest of the clusters were of solitary type means they having single gladiolus genotype in their cluster. The formation of solitary clusters may be due to total isolation preventing the gene flow or intensive natural/human selection for diverse adaptive complexes. These genotypes may be very unique and useful in breeding point of view.Divergence values $\left(D^{2}\right.$ value) ranged from zero to 7.97 indicating considerable amount of moderate variability in the material studied. All the 30 genotypes were randomly distributed into eight clusters (Table 4).

The intra cluster $\mathrm{D}^{2}$ values ranged from zero (ClustersV,VII and VIII) to 7.97 (Cluster I) indicating moderate diversity (Table 5). Cluster III was largest comprised 9 genotypes followed by cluster-II comprised seven genotypes, cluster-IV having six genotypes, cluster-VI with two genotypes, and clusterV,VII and VIII were solitary.

The formation of distinct solitary clusters may be due to the fact that they have recorded too high and too low cluster mean values (Table 6). The cluster $\mathrm{V}$ recorded highest cluster mean value for corm weight (77.63 gm), corm diameter $(7.03 \mathrm{~cm})$ and rachis length $(49.91 \mathrm{~cm})$. Cluster VII recorded the highest mean values for taken for sprouting (14.33 days), spike girth $(0.88 \mathrm{~cm})$. Highest mean values for leaf width $(5.10 \mathrm{~cm})$, maximum days taken for full spike emergence (97.07 days), high inter floret length (10.65), floret diameter $(13.12 \mathrm{~cm})$ and vase life (12.38 days) was recorded by cluster VIII. Since these traits had contributed highest towards genetic divergence such clusters may have been formed.These findings are in accordance with Sheikh and Khanday (2008) which indicated that estimation of genetic diversity among tested genotypes of gladiolus was highly significant,Maximum cluster means for floral and vegetative traits were recorded for cluster-IV and V respectively, suggesting a wide range of diversity for most of the economic traits that would enable breeder to identify

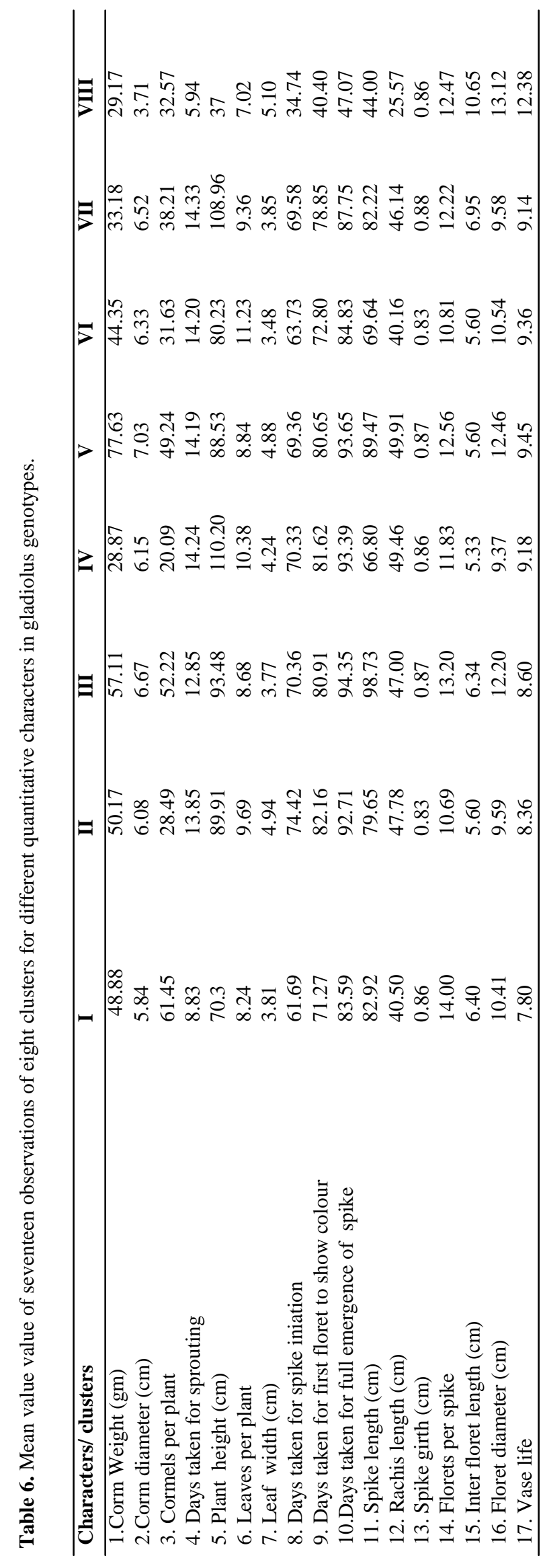


the genotypes with suitable traits to be used in direct selection and also in improvement programme for broadening the genetic base.

In present study, genotypes from cluster V, VII and VIII can be chosen for hybridization programme as cluster $\mathrm{V}$ recorded the high cluster mean values for four important characters followed by cluster VIII, which showed highest cluster mean values for five characters. Most of these were important flower attributing characters. These clusters can be preferred in selecting the genotypes for the respective traits as they recorded good means. In previous study, Panwar et al (2011) in Rose genotypes and Kavitha and Anburani (2009) in Marigold genotypes reported similar results depending upon the mean value the varieties can be used as parents in the hybridization programme for the higher yield. These genotypes have better means for yield and yield contributing characters and are placed in different clusters showing great genetic diversityIn breeding programme, parents having high flower quality potential with wide genetic diversity are likely to yield superior segregants within short period. In the present study, clusters I and VII recorded highest intra cluster distance, hence crosses may be made between genotypes of cluster VII with genotype light purple in order to obtain better segregants.

The genetic divergence analysis revealed presence of substantial amount of genetic variability among the genotypes of gladioulus crop. The pattern of distribution of genotypes in to various clusters in random showing that geographical diversity and genetic diversity are not releated to each other.

In the present study, it was revealed that within the collection of 30 gladiolus, morphological variation was observed in terms of plant height, spike length and number of florets per spike which are important traits for identification, characterization and grouping of genotypes from clusters V, VII and VIII can be chosen for hybridization programme.The choice of parents is of paramount importance in breeding programmes where crosses are to be assessed, selection based on extent of genetic divergence has been successfully utilized for the study in gladiolus genotypes.

\section{Conclusion}

Genetic diversity study indicated that among the 17 characters studied, most of the flower characters contributed towards diversity. Floret diameter contributed maximum towards genetic divergence followed by number of florets per spike, vase life, spike length and plant height. It is desirable to select genotypes from clusters having high cluster means and also with high flower character like spike length as parents for future recombination breeding programmes.

\section{REFERENCES}

Bushman, J.C.M. (1990). Gladiolus as a cut flower in subtropical and tropical regions. International Flower Bulb Center, Holland

Desh Raj, R.L. and Misra, R. L. (1996). Genetic variability in Gladiolus. J. Orn. Hort. 4 (1-2) : 1-8.

Kavitha, R. and Anburani, A. (2009). Genetic diversity in African marigold (Tagetes erecta L.) genotypes. J. Orn. Hort., 12 (3): 198-201.

Murthy, B. R.,Tiwari, J. L. (1967). The influence of dwarfing genes on genetic diversity in Pennsetum typoides. Indian J. Genet. 27: 226-237. Please Keep this referencePal, S. L., Prasad, A,and Singh, R. A. [(2006)]. Analysis of genetic divergence in gladiolus. Indian $J$. Hor., $t 63$ (1) : 70-72.

Panwar Sapna, Singh, Kanwar, P., Namitha. and Sonah, Humira. (2010). Genetic divergence analysis in Rose (Rosa X Hybrida) using morphological markers. J. Orn. Horti., 13(2): 122-126.

Sheikh, M. Q. and Khanday, B. A.(2008), Genetic diversity in gladiolus (Gladiolus hybrida L.) under two environments. J. Orn. Hort., New Series, 11(3): 216-219.

Siddique, J.A. and Swaminathan, M. S. (1971), Interspecific differentiation in Gossypium arboretum. Indian J. Genet., .31: 55-62.

Singh,R.K. and Chaudharry,B.D. (1977). Biometrical methods in quantitative genetic analysis.Kalyani Publishers, New Delhi.

Wen,C.S. and Hsiao,J.Y. (2004). Altitudinal genetic differentiation and diversity of Tiwan lily using RAPD markers and morphological characters.Int J.Plant Sci.162:287-296. 